\title{
PROBLEMATIKA IMPLEMENTASI KURIKULUM 2OI3 DALAM ASPEK PEMBELAJARAN DI MADRASAH
}

\author{
Mustaqim 1), Darnoto') \\ ${ }^{1}$ Universitas Islam Negeri Walisongo Semarang \\ mustaqimsamadi@yahoo.co.id \\ ${ }^{2}$ Unversitas Islam Nahdlatul Ulama Jepara \\ darnoto@unisnu.ac.id
}

\begin{abstract}
ABSTRAK
Penelitian ini difokuskan pada aspek pembelajaran berdasarkan kurikulum 2013 yang meliputi penyusunan perencanaan pembelajaran, pelaksanaan pembelajaran dan evaluasi proses dan hasil pembelajaran. Tujuan penelitian ini untuk mengetahui implementasi kurikulum 2013 dalam aspek proses pembelajaran di Madrasah Ibtidaiyah, Madrasah Tsanawiyah dan Madrasah Aliyah di Kabupaten Jepara dan untuk mengetahui faktor-faktor pendukung dan faktor-faktor penghambatnya serta untuk mengetahui upaya-upaya apa yang sudah dilakukan untuk mengatasi hambatanhambatan tersebut oleh para pengelola madrasah. Pendekatan penelitian ini adalah kualitatif dengan jenis deskriptif analitis, yang akan menghasilkan data berupa kata-kata, gambar-gambar dan sebagian besar bukan angkaangka kalaupun ada angka hanya sebatas sebagai pelengkap agar penggambaran tentang suatu obyek penelitian menjadi mudah dipahami. Penelitian ini dilakukan di madrasah pendampingan yaitu: Madrasah Ibtidaiyah Hasyim Asy'ari Bangsri, MTs Matholibul Huda Mlonggo dan MA Matholibul Huda Mlonggo, ketiganya berada di wilayah kabupaten Jepara bagian utara. Sedang teknik yang dipakai oleh peneliti dalam pengumpulan data adalah observasi, wawancara dan dokumentasi, adapun teknik analisis data, peneliti menggunakan pola dari Milles dan Huberman, yaitu dengan tiga alur kegiatan yang berjalan bersamaan, berlangsung secara terus menerus sampai penelitian selesai yaitu reduksi data, penyajian data dan penarikan kesimpulan atau verifikasi. Dari data yang berhasil dikumpulkan, kemudian dianalisis dan ditarik kesimpulan, bahwa guru madarasah baik MI, MTs, maupun MA sebagian sudah melaksanakan dengan sangat baik dan lengkap, sebagian sudah melaksanakan baik dan agak lengkap, tetapi sebagian masih ada yang melaksanakan dengan prosentase kecil, bahkan ada yang belum melaksanakan, meskipun prosentasenya kecil, hal tersebut disebabkan oleh banyak faktor diantaranya adalah derajat pemahamanya masih rendah dan masih heterogen, hanya sebagian kecil yang sudah memahaminya, bahkan ada sebagian kecil yang belum paham, serta faktor sarpras/media pembelajaran
\end{abstract}


yang belum memadai sebagai pendukung penting dalam pembelajaran saintific.

Kata Kunci: Kurikulum 2013, Aspek Pembelajaran

\begin{abstract}
This study focuses on aspects of learning based on the 2013 curriculum which includes the preparation of learning planning, implementation of learning and evaluation of learning processes and results. The purpose of this study was to determine the 2013 curriculum implementation in the aspects of the learning process in the Islamic Elementary School, Madrasah Tsanawiyah and Madrasah Aliyah in Jepara Regency and to find out the supporting factors and inhibiting factors and to find out what efforts have been made to overcome obstacles. This obstacle is by madrasah managers. This research approach is qualitative with analytical descriptive type, which will produce data in the form of words, pictures and most not numbers even if there are numbers only as a complement so that the description of an object of research becomes easily understood. The research was conducted in mentoring madrassas namely: Ibtidaiyah Madrasah Hasyim Asy'ari Bangsri, MTs Matholibul Huda Mlonggo and MA Matholibul Huda Mlonggo, all of them in the northern Jepara district. While the technique used by researchers in data collection is observation, interviews and documentation, as for data analysis techniques, researchers use the pattern of Milles and Huberman, namely with three flow of activities that run simultaneously, lasting continuously until the research is complete, namely data reduction, presentation data and conclusion drawing or verification. From the data collected, then analyzed and drawn conclusions, that madarasah teachers both MI, MTs, and MA are partially implemented very well and completely, some have implemented well and are rather complete, but some still implement small percentages, even some have not implemented, even though the percentage is small, it is caused by many factors including the understanding level is still low and still heterogeneous, only a small number have understood it, there are even a few who do not understand, and the sarpras / learning media factors that are not yet adequate important support in scientific learning.
\end{abstract}

Keywords: 2013 curriculum, learning aspect 


\section{PENDAHULUAN}

Salah satu faktor yang ikut mempengaruhi hasil pendidikan adalah kurikulum, yang di dalamnya meliputi tujuan, bahan ajar/materi ajar, pembelajaran dan sistem evaluasinya. Dalam implementasi kurikulum tersebut sangat dipengaruhi oleh kepemimpinan akademik kepala sekolah dan para guru di kelas dalam melakukan pembelajaran, oleh karena itu para aktor tersebut harus mendapat perhatian khusus dari semua pihak yang terkait. Hal tersebut tampaknya sudah mulai ada tanda-tanda mengarah kesana antara lain pernyataan Mendikbud Anies Baswedan tiga tahun yang lalu, dia mengutarakan kepala sekolah dan guru harus diperkuat, guru harus dilatih dengan metode yang tepat, mengubah pola pikirnya, seperti metode akupuntur, dalam metode akupuntur itu titiknya kecil dan tidak sakit, tetapi efeknya sistemik (Suara Merdeka, Semarang, Rabu tanggal 4 Februari 2015, halaman 9).

Jika dilihat dari sisi teori pembelajaran kurikulum 2013 menggunakan pendekatan saintifik, hal ini diharapkan akan bisa mengantarkan anak untuk berfikir analitis sintesis berbasis data yang pada gilirannya mereka akan menjadi manusia Indonesia yang kreatif, meskipun di awal masa mantan mendikbud Anis Baswedan ada keraguan untuk melanjutkan pemberlakuan kurikulum ini, sehingga tampak ada perbedaan pandangan dengan menteri sebelumnya (Muhammad Nuh) seperti diberitakan oleh Tribunnews.com, tanggal 7 Desember 2014.

Kurikulum 2013 merupakan kurikulum terbaru yang dibuat dan diberlakukan oleh pemerintah untuk mendukung kemajuan pendidikan di Indonesia. Banyak wacana pro dan kontra dalam awal-awal pemberlakuan kurikulum 2013 ini, diantara yang paling santer adalah perbedaan pandangan antara dua mantan menteri yaitu Anis Baswedan dan Mummad Nuh. Dalam berbagai media Anis menyebut bahwa pelaksanaan kurikulum 2013 dianggap prematur karena kesiapan sekolah dan guru yang masih sangat kurang.

Mantan Mendikbud M. Nuh menanggapi kritik Anies Baswedan dengan pernyataan sebagai berikut: "Mantan Menteri Pendidikan dan Kebudayaan, Mohammad Nuh, menilai kebijakan Kementrian Kebudayaan dan Pendidikan Dasar dan Menengah kembali pada Kurikulum 2006 adalah langkah mundur. Kurikulum 2013 secara substansi dinilainya tidak ada masalah. "Kalau ada masalah teknis, mestinya dicarikan solusi perbaikannya, bukan balik ke belakang sebab KTSP secara substansi ada kekurangan dan secara teknis juga perlu penyiapan lagi," kata Nuh di Surabaya, Minggu (7/ 12/2014), 
Seperti dikutip Antara. Nuh menjelaskan, bukti Kurikulum 2013 tidak ada masalah secara substansi adalah dengan tetap diberlakukannya untuk 6.221 sekolah. Jika ada masalah, kata dia, maka tentu tidak akan dipakai sama sekali. "Untuk itu, mestinya, alternatifnya ya penerapannya tidak langsung 'dibajak' dengan dibatasi pada 6.221 sekolah itu, melainkan sekolah mana saja yang siap, ya dipersilakan menerapkannya, apakah siap secara mandiri atau siap berdasarkan penilaian pemerintah" katanya.

Mantan Mendikbud Anis Baswedan memberi komentar seperti yang dimuat dalam Kompas.com pada hari senin tanggal 8 Desember 2014 pada pukul 12:43 WIB, di bawah judul "dikritik M. Nuh soal penghentian kurikulum 2013, Ini Komentar Anies Baswedan" sebagai berikut: "Anies menjelaskan, penerapan Kurikulum 2013 tidak diimbangi dengan kesiapan pelaksanaan. la juga menyebut substansi pelaksanaan kurikulum tersebut tidak jelas dan tidak terdokumentasi dengan baik, "tidak ditemukan penjelasan (mengapa) Kurikulum 2006 diubah dengan Kurikulum 2013. Kajiannya mana? Dokumennya mana? Mana buktinya kalau Kurikulum 2006 lemah sehingga perlu diubah?" kata Anies di Kompleks Istana Kepresidenan, Jakarta, Senin (8/ 12/ 2014).

Dimintai tanggapan mengenai kritik dari mantan Menteri Pendidikan dan Kebudayaan Mohammad Nuh, Mantan Rektor Universitas Paramadina itu mengaku tidak ingin menyalahkan Kurikulum 2013. Anies hanya menyayangkan karena penerapan kurikulum tersebut sangat tergesa-gesa. Anies menuturkan, banyak guru dan siswa yang keberatan akibat ketergesaan menerapkan Kurikulum 2013. Padahal, kata Anies, guru adalah kunci utama untuk menyukseskan penerapan kurikulum tersebut. "Kurikulum berubah, tidak otomatis kualitas pendidikan meningkat. Namun, jika kualitas guru meningkat, pendidikan kualitasnya pasti meningkat, itu kuncinya," ujar Anies.

Anies sebelumnya menginstruksikan sekolah yang belum menggunakan Kurikulum 2013 selama tiga semester untuk kembali ke Kurikulum 2006. Sementara itu, sekolah yang telah menjalankannya selama tiga semester diminta tetap menggunakan kurikulum tersebut sembari menunggu evaluasi dari pihak berwenang. (Baca: Mulai Semester Genap, Kurikulum 2013 Dihentikan)" Dalam kesempatan lain Anies Baswedan mengutarakan penjelasan dalam judul: Mendikbud Anies Baswedan Hentikan Kurikulum 2013. 
"Menteri Pendidikan dan Kebudayaan (Mendikbud) Anies Rasyid Baswedan memutuskan untuk menghentikan pelaksanaan Kurikulum 2013 di seluruh Indonesia. Kurikulum 2013 selanjutnya diperbaiki dan dikembangkan melalui sekolah-sekolah yang sejak Juli 2013 telah menerapkannya. "Proses penyempurnaan Kurikulum 2013 tidak berhenti, akan diperbaiki dan dikembangkan, serta dilaksanakan di sekolahsekolah percontohan yang selama ini telah menggunakan Kurikulum 2013 selama 3 semester terakhir," pernyataan mantan Mendikbud Anies Baswedan di Kemdikbud Jakarta, Jumat (05/ 12/ 2014).

Implementasi Kurikulum 2013 secara bertahap dan terbatas telah dilakukan pada Tahun Pelajaran 2013/2014 di 6.221 sekolah di 295 kabupaten/kota seluruh Indonesia. Hanya sekolah-sekolah inilah yang diwajibkan menjalankan kurikulum tersebut sebagai tempat untuk memperbaiki dan mengembangkan Kurikulum 2013 ini. Mendikbud Anies Baswedan juga menyampaikan selain sekolah tersebut, sekolah yang baru menerapkan satu semester Kurikulum 2013 akan tetap menggunakan Kurikulum 2006 sampai mereka benar-benar siap menerapkan Kurikulum 2013. "Sekolah-sekolah ini supaya kembali menggunakan Kurikulum 2006," katanya.

Kementerian Pendidikan dan Kebudayaan (Kemdikbud) mengambil keputusan ini berdasarkan fakta bahwa sebagian besar sekolah belum siap melaksanakan Kurikulum 2013 karena beberapa hal, antara lain masalah kesiapan buku, sistem penilaian, penataran guru, pendampingan guru dan pelatihan Kepala Sekolah" (kemdikbud.go.id,diunduh Kamis tgl.19 pebruari 2015 pukul 8,48 WIB)

Sedang dalam Permendikbud no. 160, tahun 2014, tgl 11 Desember 2014 secara rinci dimuat dalam beberapa pasal, sebagai berikut:

Pasal. 1. Satuan pendidikan dasar dan pendidikan menengah yang melaksanakan Kurikulum 2013 sejak semester pertama tahun pelajaran 2014/ 2015 kembali melaksanakan Kurikulum Tahun 2006 mulai semester kedua tahun pelajaran 2014/ 2015 sampai ada ketetapan dari Kementerian untuk melaksanakan Kurikulum 2013. Sedang dalam Pasal. 2

(1) Satuan pendidikan dasar dan pendidikan menengah yang telah melaksanakan Kurikulum 2013 selama 3 (tiga) semester tetap menggunakan Kurikulum 2013.

(2) Satuan pendidikan dasar dan pendidikan menengah yang melaksanakan Kurikulum 2013 sebagaimana dimaksud pada ayat (1) merupakan satuan pendidikan rintisan penerapan Kurikulum 2013. 
(3) Satuan pendidikan rintisan sebagaimana dimaksud pada ayat (2) dapat berganti melaksanakan Kurikulum Tahun 2006 dengan melapor kepada dinas pendidikan provinsi/kabupaten/kota sesuai dengan kewenangannya.

Dalam Pasal. 4. Satuan pendidikan dasar dan pendidikan menengah dapat melaksanakan Kurikulum Tahun 2006 paling lama sampai dengan tahun pelajaran 2019/2020. Tampak bahwa alasan untuk kembali ke kurikulum 2006 karena para pelaku pendidikan terutama kepala sekolah/madrasah dan para guru belum siap. Pertanyaannya berikutnya adalah dalam hal apa para guru tersebut belum siap? Kesulitan-kesulitan riil apa yang mereka hadapi jika benar-benar melaksanakan kurikulum 2013? Apakah kesulitan tersebut seluruhnya tidak bisa diselesaikan? Atau sebagian bisa diatasi dan sebagian belum?

Banyak pertanyaan yang bisa diajukan, dan karena ini adalah suatu hal baru maka perlu dilakukan kajian segera. Apalagi ternyata madrasah di kabupaten Jepara yang memperoleh izin melaksanakan kurikulum 2013 , hanya 3 madarasah yaitu MI Hasyim Asyari Bangsri Jepara ,MTs. MH Mlonggo Jepara dan MA MH Mlonggo Jepara (Keputusan Direktur Pendidikan Islam nomor 481 thn 2015). Melihat pentingnya sebuah proses pembelajaran, yang oleh Edward Saillis dinyatakan bahwa "proses pembelajaran" merupakan ruh dari sebuah proses pendidikan, sejalan dengan yang dikemukakan Sallis dalam Total Quality Management in Education (2008: 86), ia mengemukakan bahwa pendidikan adalah tentang pembelajaran, institusi pendidikan harus menfokuskan diri pada mutu pembelajaran. Berdasarkan hal tersebut, guru yang merupakan aktor utama proses pembelajaran merupakan orang yang sangat bertanggung jawab terhadap keberhasilan pendidikan di sekolah.

\section{METODE PENELITIAN}

Penelitian ini menggunakan pendekatan kualitatif dengan jenis analitis deskriptif. Data-data yang disajikan akan berbentuk kata-kata, gambar, yang sebagian besar bukan berupa angka-angka, kalaupun ada angka ia hanya sebatas pelengkap agar penggambaran data tentang obyek penelitian tersebut menjadi mudah dipahami. Penelitian ini dilakukan di kota Jepara bagian utara dengan mengambil tiga madrasah yang menjadi obyek penelitian. Ketiga madrasah tersebut adalah Madrasah Ibtidaiyah Hasyim Asy'ari Bangsri, MTs. Matholibul Huda Mlonggo dan MA. Matholibul Huda Mlonggo, pemilihan ketiga madrasah ini didasarkan karena ketiga sekolah ini 
merupakan pilot project pelaksanaan kurikulum 2013 di madrasah sesuai dengan keputusan Keputusan Direktur Pendidikan Islam Nomor 481 Tahun 2015.

Sementara teknik pengambilan data dilakukan dengan interview, observasi, dan dokumentasi. Teknik wawancara dilakukan dengan melakukan wawancara kepada pimpinan madrasah, para guru pengampu mata pelajaran, serta tenaga kependidikan, wawancara ini dilakukan secara terstruktur. Teknik observasi, dilakukan dengan melihat secara langsung real teaching yang dilakukan oleh para guru mata pelajaran agama Islam, dan dilakukan juga terhadap kondisi suasana kelas ketika dilangsungkan proses pembelajaran. Teknik dokumentasi, digunakan untuk mengumpulkan dokumentasi-dokumentasi tentang rencana pembelajaran, dokumendokumen tentang instrumen yang dipakai untuk mengukur derajat pencapaian belajar siswa yang terdapat dalam dokumen evaluasi dan dokumen hasil belajar serta portofolio para peserta didik.

Teknik Analisis data, menggunakan pola dari Milles dan Huberman, yaitu dengan tiga alur kegiatan yang berjalan bersamaan, berlangsung secara terus menerus sampai penelitian selesai yaitu reduksi data, penyajian data dan penarikan kesimpulan atau verifikasi.

\section{PEMBAHASAN}

Dari hasil analisa data tentang proses pembelajaran kurikulum 2013 yang dilaksanakan pada tiga obyek penelitian ini yaitu di Madrasah Ibtidaiyah Hasyim Asy'ari Bangsri, MTs Matholibul Huda Mlonggo dan MA Matholibul Huda Mlonggo dapat penulis kemukakan beberapa temuan bahwa dalam implementasi kurikulum tersebut sangat dipengaruhi oleh kepemimpinan akademik kepala sekolah dan para guru di kelas dalam melakukan pembelajaran, oleh karena itu para pihak tersebut harus mendapat perhatian lebih dari semua stakeholder yang terkait.

\section{Pemahaman Guru Terhadap Konsep Kurikulum 2013}

Kata kunci dari sebuah proses pembelajaran adalah pemahaman guru yang sesuai/ sejalan dengan paradigma sebuah kurikulum yang diterapkan. Pemahaman tentang paradigma kurikulum yang utuh akan berimbas pada cara penyampaian bahan ajar yang tepat. Sehingga tujuan dari perubahan kurikulum yang dilaksanakan akan membawa kepada tujuan yang tepat sasaran. Pernyataan tersebut tentu saja mengarah kepada guru terutama dan sekolah sebagai lembaga pelayanan 
pendidikan. Hal ini sejalan dengan yang dinyatakan Nasution bahwa kurikulum merupakan suatu rencana yang disusun untuk membantuk kelancaran proses belajarmengajar yang dibimbing dan atas tanggung jawab sekolah beserta staf pengajarnya (Nasution, 2009:5).

Jika kita melihat pengertian pembelajaran yang dimuat dalam lampiran Peraturan Menteri Pendidikan dan Kebudayaan Republik Indonesia nomor 103 tahun 2014 tentang pembelajaran pada pendidikan dasar dan pendidikan menengah, bahwa "Pembelajaran adalah proses interaksi antar peserta didik, antara peserta didik dengan tenaga pendidik dan sumber belajar pada suatu lingkungan belajar". Maka peran pendidik mutlak ada dalam sebuah pembelajaran, terutama untuk mengubah konsep pemahaman yang baru pada sebuah kurikulum yang sedang diterapkan.

Dari hasil analisis data di lapangan, didapat data bahwa pemahaman guru terhadap konsep Kurikulum 2013 dinyatakan sebagai berikut ini:

\begin{tabular}{llllll}
\hline No. & $\begin{array}{l}\text { Jenjang } \\
\text { Madrasah/ } \\
\text { Sekolah }\end{array}$ & $\begin{array}{l}\text { Memahami } \\
\text { seluruh } \\
\text { konsep }\end{array}$ & $\begin{array}{l}\text { Memahami } \\
\text { sebagian } \\
\text { besar }\end{array}$ & $\begin{array}{l}\text { Memahami } \\
\text { sebagian } \\
\text { kecil }\end{array}$ & $\begin{array}{l}\text { Belum } \\
\text { memahami }\end{array}$ \\
\hline 1 & MI. & $7,14 \%$ & $53,57 \%$ & $32,14 \%$ & $7,15 \%$ \\
2 & MTs. & $9,32 \%$ & $30,68 \%$ & $50 \%$ & $6,67 \%$ \\
3 & MA. & $22 \%$ & $58 \%$ & $20 \%$ & $0 \%$ \\
\hline
\end{tabular}

Tabel 1. Pemahaman guru terhadap konsep Kurikulum 2013

Berdasarkan data tersebut, terlihat bahwa sebagian besar guru MTs masih belum memahami konsep K-13, sementara guru MI dan MA cenderung hal lebih banyak yang telah paham terhadap konsep kurikulum 2013. Upaya-upaya mengadakan pelatihan kepada guru MTs harus lebih mendapat perhatian, untuk lebih banyak diberikan stimulan-stimulan dalam penguasaan konsep K-13.

\section{Aspek-aspek Perubahan}

Dalam kurikulum 2013 ada empat elemen perubahan yaitu standar kompetensi lulusan, standar proses, standar isi dan standar penilaian (Badan Pengembangan Sumber Daya Manusia Pendidikan dan Kebudayaan dan Penjaminan Mutu Pendidikan, Kementerian Pendidikan dan Kebudayaan, 9/ 6/ 2013). Salah satu penjelasan tentang pembelajaran ini dimuat dalam lampiran Peraturan Menteri Pendidikan dan Kebudayaan nomor 67 tahun 2013 tentang Kerangka Dasar dan Struktur Kurikulum Sekolah Dasar/ Madrasah Ibtidaiyah. Dalam ayat 2.c bahwa 
penyempurnaan pola pikir Kurikulum 2013 dikembangkan dengan penyempurnaan pola pikir sebagai berikut:

1. Pola pembelajaran yang berpusat pada guru menjadi pembelajaran berpusat pada peserta didik. Peserta didik harus memiliki pilihan-pilihan terhadap materi yang dipelajari untuk memiliki kompetensi yang sama;

2. Pola pembelajaran satu arah (interaksi guru-peserta didik) menjadi pembelajaran interaktif (interaktif guru-peserta didik-masyarakat-lingkungan alam, sumber/ media lainnya);

3. Pola pembelajaran terisolasi menjadi pembelajaran secara jejaring (peserta didik dapat menimba ilmu dari siapa saja dan dari mana saja yang dapat dihubungi serta diperoleh melalui internet);

4. Pola pembelajaran pasif menjadi pembelajaran aktif-mencari (pembelajaran siswa aktif mencari semakin diperkuat dengan model pembelajaran pendekatan sains)

5. Pola belajar sendiri menjadi belajar kelompok (berbasis tim);

6. Pola pembelajaran alat tunggal menjadi pembelajaran berbasis alat multimedia;

7. Pola pembelajaran berbasis massal menjadi kebutuhan pelanggan (users) dengan memperkuat pengembangan potensi khusus yang dimiliki setiap peserta didik;

8. Pola pembelajaran ilmu pengetahuan tunggal (monodiscipline) menjadi pembelajaran ilmu pengetahuan jamak (multidisciplines); dan

9. Pola pembelajaran pasif menjadi pembelajaran kritis.

Penjelasan menteri pendidikan nasional yang dimuat dalam materi Penyegaran

Narasumber Pelatihan Guru untuk Implementasi Kurikulum 2013, di Jakarta, 26-28 Juni 2013, antara lain menjelaskan bahwa:

1. Standar proses yang semula terfokus pada eksplorasi, elaborasi, dan konfirmasi dilengkapi dengan mengamati, menanya, mengolah, menalar, menyajikan, dan mencipta.

2. Belajar tidak hanya terjadi di ruang kelas, tetapi juga di lingkungan sekolah dan masyarakat

3. Guru bukan satu-satunya sumber belajar.

4. Sikap tidak hanya diajarkan secara verbal, tetapi melalui contoh dan teladan

Pembelajaran pada Kurikulum 2013 menggunakan pendekatan saintifik atau pendekatan berbasis proses keilmuan. Pendekatan saintifik dapat menggunakan 
beberapa strategi seperti pembelajaran kontekstual. Model pembelajaran merupakan suatu bentuk pembelajaran yang memiliki nama, ciri, sintak, pengaturan, dan budaya misalnya discovery learning, project-based learning, problem-based learning, inquiry learning.

Kurikulum 2013 menggunakan modus pembelajaran langsung (direct instructional) dan tidak langsung (indirect instructional). Pembelajaran langsung adalah pembelajaran yang mengembangkan pengetahuan, kemampuan berpikir dan keterampilan menggunakan pengetahuan peserta didik melalui interaksi langsung dengan sumber belajar yang dirancang dalam silabus dan RPP. Dalam pembelajaran langsung peserta didik melakukan kegiatan mengamati, menanya, mengumpulkan informasi/mencoba, menalar/mengasosiasi, dan mengomunikasikan. Pembelajaran langsung menghasilkan pengetahuan dan keterampilan langsung, yang disebut dengan dampak pembelajaran (instructional effect).

Pembelajaran tidak langsung adalah pembelajaran yang terjadi selama proses pembelajaran langsung yang dikondisikan menghasilkan dampak pengiring (nurturant effect). Pembelajaran tidak langsung berkenaan dengan pengembangan nilai dan sikap yang terkandung dalam $\mathrm{KI}-1$ dan $\mathrm{KI}-2$. Hal ini berbeda dengan pengetahuan tentang nilai dan sikap yang dilakukan dalam proses pembelajaran langsung oleh mata pelajaran Pendidikan Agama dan Budi Pekerti serta Pendidikan Pancasila dan Kewarganegaraan. Pengembangan nilai dan sikap sebagai proses pengembangan moral dan perilaku, dilakukan oleh seluruh mata pelajaran dan dalam setiap kegiatan yang terjadi di kelas, sekolah, dan masyarakat. Oleh karena itu, dalam proses pembelajaran Kurikulum 2013, semua kegiatan intrakurikuler, kokurikuler, dan ekstrakurikuler,baik yang terjadi di kelas, sekolah, dan masyarakat (luar sekolah) dalam rangka mengembangkan moral dan perilaku yang terkait dengan nilai dan sikap.

\section{Proses Pembelajaran}

Pada bagian proses pembelajaran ini, penulis akan memaparkan tiga tahapan yang dilakukan, yang meliputi hal-hal sebagai berikut:

\section{Penyusunan perencanaan pelaksanaan pembelajaran}

Dari hasil analisis data di lapangan, didapat data bahwa ketaatan dan kemauan guru dalam menyusun RPP Kurikulum 2013 dinyatakan sebagai berikut ini: 


\begin{tabular}{llllll}
\hline No. & $\begin{array}{l}\text { Jenjang } \\
\text { Madrasah/Sekolah }\end{array}$ & $\begin{array}{l}\text { Selalu } \\
\text { menyusun }\end{array}$ & $\begin{array}{l}\text { Sering } \\
\text { menyusun }\end{array}$ & $\begin{array}{l}\text { Jarang } \\
\text { menyusun }\end{array}$ & $\begin{array}{l}\text { Tidak pernah } \\
\text { menyusun }\end{array}$ \\
\hline 1 & MI. & $3,57 \%$ & $35,72 \%$ & $39 \%$ & $29 \%$ \\
2 & MTs. & $8 \%$ & $52 \%$ & $40 \%$ & $0 \%$ \\
3 & MA. & $4 \%$ & $60 \%$ & $32 \%$ & $4 \%$ \\
\hline
\end{tabular}

\section{Tabel 2. Penyususan RPP Kurikulum 2013}

\section{Pelaksanaan pembelajaran di dalam kelas}

Kendala utama yang dihadapi guru pada pelaksanaan dan proses pembelajaran Kurikulum 2013 adalah, para guru kesulitan dalam mengejawantahkan pendekatan scientific pada proses di lapangan. Dalam pengamatan peneliti, pendekatan ini telah dilaksanakan tetapi tidak sesuai dengan maksud dari konsep scientific itu sendiri, dalam arti bahwa pembelajaran masih berjalan sebagai mana mereka para guru menggunakan kurikulum sebelumnya. Hal ini terlihat dari tidak sesuainya guru dalam mensinergikan perencanaan pembelajaran dengan penggunaan media dan alat pembelajaran yang dapat menunjang pengetahuan peserta didik dengan pendekatan scientific.

Penguatan tentang tata cara mengajar guru ini, diungkapkan dalam kesimpulan dari beberapa wawancara yang meliputi kendala-kendala dalam hal sebagai berikut: guru masih jarang dalam menggunakan model pembelajaran yang variatif, metode ceramah masih mendominasi teknik pembelajaran, media yang dipergunakan relatif tunggal, pembelajaran dengan melibatkan kelompok masih belum variatif hanya sebatas pada penyelesaian tugas bersama.

\section{Evaluasi pembelajaran dan tindak lanjutnya}

Evaluasi proses dan hasil belajar berdasarkan kurikulum 2013 diatur dalam permendikbud nomor 104 tahun 2014,yang mendefinisikan .."Penilaian Hasil Belajar oleh Pendidik adalah proses pengumpulan informasi/bukti tentang capaian pembelajaran peserta didik dalam kompetensi sikap spiritual dan sikap sosial, kompetensi pengetahuan, dan kompetensi keterampilan yang dilakukan secara terencana dan sistematis, selama dan setelah proses pembelajaran "(permendikbud nomor 104 tahun 2014,III/A/1).

Penilaian menggunakan Acuan Kriteria yang merupakan penilaian kemajuan peserta didik dibandingkan dengan kriteria capaian kompetensi yang ditetapkan. Skor yang diperoleh dari hasil suatu penilaian baik yang formatif maupun sumatif seorang 
peserta didik tidak dibandingkan dengan skor peserta didik lainnya namun dibandingkan dengan penguasaan kompetensi yang dipersyaratkan"(permendikbud nomor 104 tahun 2014,III/A/3). Sedang lingkup penilaian hasil belajar oleh pendidik mencakup kompetensi sikap (spiritual dan sosial), pengetahuan, dan keterampilan.

Pemahaman tentang konsep

\begin{tabular}{lcccc}
\hline \multicolumn{1}{c}{ Level } & MI & MTS & MA & MEAN \\
\hline Sangat paham/ seluruhnya & 7,14 & 9,32 & 22 & $12,82 \%$ \\
\hline Paham sebagian besar & 53,57 & 30,68 & 58 & $47,41 \%$ \\
Kurangpaham/paham sebagian kecil & 32,14 & 50 & 20 & $34,04 \%$ \\
\hline Belum paham & 7,15 & 6,67 & 0 & $4,6 \%$ \\
\hline
\end{tabular}

\section{SIMPULAN}

Implementasi kurikulum 2013 di tiga madrasah tersebut, yang ditandai dengan indikator mampu memahami perubahan paradigma kurikulum 2013 dan alasan pengembangannya, mengetahui informasi teraktual tentang perkembangan kurikulum 2013, mengetahui struktur dan pengembangan kurikulum 2013, dan mempunyai respon yang baik terhadap perubahan dan penyempurnaan kurikulum 2013, dapat dikatakan sangat baik, dengan kata lain bahwa guru SMP Negeri 33 Makassar siap untuk mengimplementasikan kurikulum 2013.Simpulan berisi rangkuman singkat atas temuan penelitian yang merupakan intisari hasil pembahasan [Arial, 12, spasi 1,5].

Khusus dalam hal perencanaan pembelajaran para guru MI Hasyim Asy'ari Bangsri.yang sudah menyusun berdasarkan ketentuan baru separo lebih sedikit,sisanya masih jarang,bahkan ada yang belum pernah menyusun sendiri,meskipun jumlahnya sedikit.Sedang dalam implentasi pembelajaran dengan pendekatan saintific guru Ml yang sudah melaksakan penuh baru sekitar seperempat,sisanya masih belum dan jarang melakukannya.Dalam pelaksanaan evaluasi otentic guru MI yang sudah melaksanakan masih sedikit,sebagian besar belum melaksanakannya,hal disebabkan oleh banyak faktor. Sedang Guru MTs sudah banyak,lebih dari separo yang menyusun RPP sendiri,namun dalam implementasi pembelajaran dengan pendekatan saintific guru MTs masih separo lebih yang belum,bahkan untuk implentasi evaluasi autentic baru sedikit yang sudah melaksanakannya, hanya sekitar 12 persen saja,hal ini disebabkan oleh banyak faktor.Selanjutnaya dalam penyusunan RPP sesuai ketentuan para guru MA sudah 
sebagian besar melaksanakannya,tetapi masih ada sekitar sepertiganya belum.Sedang dalam pelaksanaan pembelajaran dengan pendekatan saintific juga sebagian besar sudah melaksanakannya,hanya sekitar seperempat saja yang belum.Demikian pula dalam hal evaluasi autentic,para guru MA sebagian besar sudah melaksanakannya,namun masih ada sekitar sepertiganya belum melaksanakan karena banyak faktor.Faktor-Faktor yang mempengaruhi implementasi kurikulum 2013 ,menurut pengakuan para guru antara lain:RPP belum tersedia contoh per mata pelajaran,sarana pendukung masih kurang memadai, pelatihan guru yang merata dan intensif,guru kurang memahami tentang kurikulum 2013,perlu uji coba/ pelatihan dengan intensif,perlu MGMP lokal yang bisa menjadi tempat berdiskusi,belum ada proyektor/lcd,buku ajar belum cukup,hanya sebagian kecil yg tersedia,ruang perpustakaan kurang luas,sehingga mengganggu explorasi,perlu buku panduan yang lengkap dan detail,proses penilaian rumit,sehingga sulit dan lama,buku pendamping siswa belum tersedia dan perlu buku pegangan khusus untuk guru,media pembelajaran kurang memadai, ini mengganggu proses observing,video pembelajaran belum tersedia, yang memungkinkan proses pembelajaran yang menyenangkan dan mengurangi verbalisme. Sedang upaya-upaya yang sudah dilakukan untuk mengatasi problem-problem dalam implementasi kurikulum 2013, antara lain menghadirkan narasumber untuk pelatihan/bintek para guru secara periodik yang didanai mandiri (MI, MTs, MA),mengundang nara sumber untuk melakukan pendampingan bagi para guru terutama untuk menyusun RPP dan Instrumen penilaian (MTs dan MA),mengirimkan beberapa guru untuk mengikuti bimbingan teknis kurikulum 2013 yang diselenggarakan Kemenag (MI, MTs, MA),melakukan diskusi kelompok guru secara menyeluruh, seluruh guru bidang studi saat liburan sekolah (8 hari penuh) ini hanya dilakukan MA saja,penularan pengalaman guru tiap-tiap selesai mengikuti pelatihan kurikulum 2013 kepada guruguru yg lain tidak ikut pelatihan (MI, MTs, MA), serta Belajar mandiri dari sekolah/madrasah tetangga yang sudah mengimplementasikan kurikulum 2013.

\section{DAFTAR PUSTAKA}

Agus Pribadi, Benni. 1996. Media Pendidikan. Jakarta: Universitas Terbuka

Atwi Suparman, M. 2001. Desain Instruksional. Pusat Antar Universitas Untuk Peningkatan dan Pengembangan Aktivitas Instruksional Universitas Terbuka: Jakarta 
Azhar, Arsyad. 2000. Media Pengajaran. PT. Raja Grafindo: Jakarta

Depdikbud, 2007. Kamus besar Bahasa Indonesia. Balai Pustaka: Jakarta

Dewiyati. 2017. "Implementasi Kurikulum 2013 Di Smk Negeri 1 Kahayan Hilir Kabupaten Pulang Pisau". Jurnal Ilmiah Ekonomi Bisnis. 3 (3): 443 - 450

E. Smaldino, Sharon., L.Lowther, Deborah., D.Russell, James. 2012. Intructional Technology and Media For Learning. terj. Arif Rahman. Kencana: Jakarta

Eko Indrajid, R., Djokopranoto, R. 2006. Manajemen Perguruan Tinggi Modern. CV. Andi: Yogyakarta

F.Silver, Harvey., W. Strong, Richard., J.Parini, Matthew. 2012. The Strategic Teacher. terj. Ellys Tjo. PT Indeks: Jakarta

Hadi Miarso, Yusuf. 1998. Model Pengembangan Instruksional. Proyek Pengembangan Pusat Fasilitas Bersama Antar Universitas

Hamalik, Oemar. 2010. Manajemen Pengembangan Kurikulum. PT. Remaja Rosdakarya: Bandung.

Hayat, Bahrul., Yusuf, Suhendra. 2010. Benchmark Internasional Mutu Pendidikan. Bumi Aksara: Jakarta

Hoy, Wayne K., Cecil G. Miskel. 1991. Educational Administration: Theory, Research, and Practice-Fourth Edition. McGraw-Hill, Inc: New York

Idi, Abdullah. 2009. Pengembangan Kurikulum. Ar-Ruz Media: Yogyakarta

Jan Van Rossum, Erik., Hamer, Rebbeca. 2010. The Meaning Of Learning and Knowing. Sense Publishiers: Rotterdam

K. Davies, Ivor. 1986. The Management of Learning. terj. Sudarsono Sudirdjo dkk. Rajawali: Jakarta.

Kemdikbud.go.id, diunduh Kamis tgl.19 pebruari 2015 pukul 08.48 WIB.

Kemp \& Dayton. 1985. Planing dan producing Intructioanl Media (Fith Edition). Happer

\& Row Publishers: New York.

Keputusan Direktur Pendidikan Islam nomor 481 tahun 2015.

Kompas.com, senin tanggal 8 Desember 2014, pukul 12.43 WIB.

L. Silberman, Melvin. 2004. Active Learning: 101 Strategies to Teach Any Subject, terj.

Raisul Muttaqien. Nusamedia Nuansa: Bandung

Lampiran Peraturan Menteri Pendidikan dan Kebudayaan nomor 67 tahun 2013 tentang Kerangka Dasar dan Struktur Kurikulum Sekolah Dasar/Madrasah Ibtidaiyah. 
Light, Greg., Cox, Roy., Calkins, Susanna. 2008. Learning and teaching in higher education, second edition. SAGE publications Ltd.: Chicago

Muhaimin. 2012. Pengembangan Kurikulum pendidikan Agama Islam. PT.Raja Grafindo: Jakarta

Mustaqim. 2010. Psikologi Pendidikan, PustakaPelajar: Yogyakarta

Nana Sudjana. 1989. Dasar Dasar Proses Belajar Mengajar. Sinar Baru: Bandung

Nasution, S. 2009, Kurikulum dan Pengajaran. Jakarta: Bumi Aksara.

Oliva, Peter F. 1984. Supervision for Today's Schools. Second Edition. Longman: New York \& London

P. Robbin, Stephen., Coulter, Mary. 2010. Management, 10th Edition. Terj. Bob Sabran, Devri Barnadi Putra. Erlangga: Jakarta

Permendikbud Nomor 160, tahun 2014, tgl 11 Desember 2014.

Pidarta, Made. 2004. Manajemen Pendidikan Indonesia. Bumi Aksara: Jakarta.

Sadiman, Arif S. dkk. 2006. Media Pendidikan. PT. Raja Grafindo Persada: Jakarta

Sallis, Edward. 2008. Total Quality Manajemen in Education. terj. A.A.Riyadi. Ircisod: Yogyakarta

Suara Merdeka, Semarang, Rabu tgl. 4 Pebruari 2015, halaman 9.

Suharsimi, Arikunto. 1986. Dasar-dasar Evaluasi Pendidikan. Bina Aksara: Jakarta

Suryabrata, Sumadi, Prof., 1974. Psikologi Pendidikan, CV. Rajawali: Jakarta

Tribunnews.com, Minggu tanggal 7 Desember 2014, 13.27 WIB.

Usman, Husaini. 2011. Manajemen Teori, Praktek dan Riset Pendidikan. Bumi Aksara: Jakarta

UU No. 20 Tahun 2003 tentang Sistem Pendidikan Nasional 
108 | Jurnal Tarbawi Vol. 15. No. 2. Juli - Desember 2018 